\title{
Extraction of Papaya Leaves (Carica papaya L.) Using Ultrasonic Cleaner
}

\author{
Lina Fauzi’ah, Miladiatul Wakidah \\ Program Studi Pendidikan Kimia, FMIPA, Universitas Islam Indonesia \\ Jl. Kaliurang Km 14,5 Yogyakarta 55584 \\ E-mail: lina.fauziah@uii.ac.id
}

\begin{abstract}
Extraction of papaya leaves (Carica papaya L.) using Ultrasonic Cleaner has been performed. Papaya leaves were extracted for 6 hours in a methanol as solvent. The results of phytochemical screening showed that methanol extract contained secondary metabolites of flavonoids, alkaloids, tepenoid, saponin, and phenolic classes. Methanol extract was then partitioned liquid-liquid with n-hexane. Quantitative analysis of partitioning of n-hexane using papaya leaves using Gas Chromatography-Mass Spectrometry (GC-MS) showed the presence of neophytadiene (1.59\%), palmitic acid $(1.35 \%)$ and methyl linolenate (3.33\%). The results showed that Ultrasonic Cleaner can be used to ultrasonic-assisted extraction of natural products especially for papaya leaves.
\end{abstract}

Keywords: extraction, papaya leaves, ultrasonic

\begin{abstract}
Abstrak
Ekstraksi daun pepaya (Carica papaya L.) menggunakan Ultrasonic Cleaner telah dilakukan. Sampel daun pepaya diesktrak selama 6 jam dalam pelarut metanol. Hasil skrining fitokimia menunjukkan bahwa ekstrak metanol mengandung metabolit sekunder kelas flavonoid, alkaloid, tepenoid, saponin, serta fenolik. Ekstrak metanol kemudian dipartisi cair-cair dengan n-heksana. Analisis kuantitatif hasil partisi nheksana daun pepaya menggunakan kromatografi gas-spektroskopi massa (KG-SM) menunjukkan adanya neofitadiena $(1,59 \%)$, asam palmitat $(1,35 \%)$ dan metil linolenat $(3,33 \%)$. Hasil penelitian menunjukkan bahwa Ultrasonic Cleaner dapat digunakan untuk mengekstrak bahan alam dengan bantuan gelombang ultrasonik terutama untuk daun pepaya.
\end{abstract}

Kata Kunci : ekstraksi, daun pepaya, ultrasonik

\section{Pendahuluan}

Bahan alam sampai saat ini masih digunakan dalam pengobatan bahkan dijadikan sebagai sumber kajian dalam pengembangan obat (Luo, dkk., 2014). Penggunaan bahan alam sebagai obatobatan telah dimulai sejak 2600 SM.
Beberapa diantaranya minyak cedar, Cupressus, akar manis (licorice), opium, maupun minyak dari Commiphora myrrha yang sampai saat ini masih digunakan untuk mengobati batuk, pilek, infeksi parasit, maupun peradangan (Cragg dan Newman, 
2013). Di Indonesia, beberapa produk bahan alam yang digunakan untuk pengobatan diantaranya adalah minyak biji adas, minyak gandapura, serta minyak kayu putih. Pemakaian bahan alam sebagai obat tradisional juga mempelopori studi tentang kandungan senyawa aktif dari bahan alam yang dapat dimanfaatkan untuk mengobati penyakit seperti malaria, kanker, infeksi mikroba, serta tumor.

\section{Pepaya (Carica papaya L.)} termasuk tanaman family Caricaceae yang berkeping biji dua (dikotil) serta poligamus. Pepaya adalah tanaman semi-kayu, biasanya berbatang tunggal dan tersebar di daerah tropis dan subtropis (Jiménez, dkk., 2013). Daun pepaya telah dilaporkan memiliki beberapa manfaat, yaitu anti-tumor (Otsuki, dkk., 2010), mengobati demam berdarah (Ahmad, dkk., 2011), dan memiliki antioksidan (Vuong, dkk., 2013). Kandungan metabolit sekunder dari daun pepaya adalah flavonoid (Nugroho, dkk., 2017; Maisarah, dkk., 2013), alkaloid (Julianti, dkk., 2014), fenolik (Maisarah, dkk., 2013), terpenoid (Ayoola, dkk., 2008), serta saponin (Ayoola, dkk., 2008; Ayoola dan Adeyeye, 2010).

Prosedur analisis dari bahan alam terdiri dari tiga tahap, yaitu ekstraksi, evaporasi, serta analisis. Dari ketiga tahap tersebut, tahap ekstraksi adalah tahap paling lama, membutuhkan waktu berjam-jam bahkan berhari-hari, dan sering dilakukan dengan pemanasan berkepanjangan dan diaduk dalam pemanasan pelarut secara berkepanjangan (Chemat, dkk., 2015). Ekstraksi adalah langkah yang terpenting untuk recovery dan pemurnian senyawa aktif dari bahan alam (Wu, dkk., 2001). Ekstraksi bahan alam dapat dilakukan dengan metode maserasi, infusdasi, sokhletasi, perkolasi, maupun digesti (Atun, 2014). Ekstraksi maserasi sangat sederhana dan ekonomis, namun memiliki kelemahan, yaitu memerlukan pelarut yang banyak dan waktu yang lama (Sari, dkk., 2013). Maserasi membutuhkan pelarut dengan perbandingan sekurangkurangnya 1:7, waktu dari 1-6 hari, serta membutuhkan tahap remaserasi (Atun, 2014). Hal ini bertentangan dengan prinsip kimia hijau ke 5, Safer solvent and auxilary. Penerapan prinsip kimia hijau ke-5 mengharuskan penghilangan pemakaian pelarut dan agen pemisah jika memungkinkan.

Penggunaan metode ekstraksi berbantuan ultrasonik (Ultrasound Assisted-extraction, UAE) merupakan salah satu solusi yang dapat dilakukan 
untuk menghemat energi, mereduksi penggunaan pelarut, serta dapat mengurangi waktu dan biaya ekstraksi (Wu, dkk., 2001; Chemat, dkk., 2017). Selain itu, UAE berlangsung pada temperatur di bawah titik didih pelarut sehingga dapat menghindari kerusakan senyawa hasil ekstrak akibat pemanasan dan kehilangan senyawa yang berisifat volatil (Wu, dkk., 2001). Ekstraksi berbantuan ultrasonik dapat dilakukan dengan cara sokhletasi, distilasi Clevenger, ekstraksi berkelanjutan, maupun dengan bantuan microwave, ekstruksi, dan cairan superkritis.

Ultrasonic Cleaner merupakan alat yang digunakan untuk membersihkan barang, seperti perhiasan, lensa dan bagian optik lainnya, jam tangan, serta peralatan bedah. Alat ini dapat menimbulkan irradiasi gelombang ultrasonik dalam bentuk kavitasi yang akan terbentuk pada permukaan pelarut melalui suatu getaran. Penelitian ini bertujuan untuk mengetahui penggunaan alat Ultrasonic Cleaner untuk ekstraksi daun pepaya (Carica papaya L.), skrining fitokimia dan analisis kandungan senyawa dengan KG-SM.

\section{Metode Penelitian}

\section{Alat dan Bahan}

Sampel daun pepaya (Carica papaya L.) didapatkan dari Cangkringan, Sleman, Yogyakarta. Bahan yang digunakan dalam penelitian ini meliputi: metanol (p.a. Merck), akuades, feri klorida, asam klorida (p.a. Merck), serbuk magnesium, asam sulfat (p.a. Merck), iodin, kalium iodide, asam asetat glasial (p.a. Merck), n-heksana, aseton, kloroform, plat KLT, pipa kapiler. Peralatan yang digunakan dalam penelitian ini yaitu corong gelas, gelas beker, pipet tetes, tabung reaksi, pipet ukur, bola hisap, Ultrasonic Cleaner Delta D68H, evaporator, kromatografi gas-spektroskopi massa (KG-SM).

\section{Ekstraksi Daun Pepaya}

Sampel daun pepaya dipotong kecil-kecil, dicuci dengan air mengalir kemudian ditiriskan. Sampel dioven selama 25 menit pada suhu $105{ }^{\circ} \mathrm{C}$, ditimbang sebanyak 20 gram dan ditambah pelarut metanol sebanyak 100 $\mathrm{mL}$ kemudian diekstrak dalam Ultrasonic Cleaner Delta D68H selama 6 jam. Hasil ekstraksi kemudian dievaporasi sehingga didapatkan ekstrak kental berwana hijau.

Skrining Fitokimia 


\section{Uji Saponin}

Ekstrak metanol ditambah dengan air (1: 1) kemudian dikocok selama 5 menit. Adanya busa yang dapat bertahan selama 30 menit menunjukkan adanya senyawa saponin.

\section{Uji Flavonoid}

Ekstrak metanol dimasukkan dalam tabung reaksi kemudian ditambahkan serbuk Magnesium sebanyak 1 gram dan larutan asam hidroklorida pekat 5 tetes. Adanya senyawa flavonoid ditandai dengan perubahan warna menjadi warna merah, kuning atau jingga.

\section{Uji Terpenoid}

Ekstrak metanol dimasukkan dalam tabung reaksi lalu ditambahkan $1 \mathrm{~mL}$ asam asetat glasial dan $1 \mathrm{~mL}$ asam sulfat pekat. Jika larutan berubah warna menjadi merah menunjukkan adanya senyawa terpenoid.

\section{Uji Alkaloid}

Ekstrak metanol diuji dengan pereaksi Wagner. Endapan cokelat menunjukkan adanya senyawa alkaloid.

\section{Uji Fenolik}

Ekstrak metanol ditambahkan 3 tetes larutan feri klorida. Sampel yang mengandung fenolik akan mengalami perubahan warna menjadi hijau violet/biru tua/hitam kehijauan.

Ekstrak metanol diduga masih mengandung beberapa molekul besar dan metabolit primer yang akan mengganggu proses analisis, sehingga dilakukan partisi cair-cair dengan pelarut n-heksana. Fasa n-heksana digunakan untuk analisis kuantitatif dengan KG-SM.

\section{Hasil dan Pembahasan}

Ekstraksi daun pepaya dengan bantuan gelombang ultrasonik yang dihasilkan dari Ultrasonic Cleaner telah dilakukan dengan pelarut metanol. Pelarut metanol dipilih karena dapat mengekstrak sebagian besar kandungan senyawa yang ada pada bahan alam. Ultrasonic Cleaner Delta D68H merupakan alat yang biasa digunakan untuk membersihkan barang-barang, seperti jam, perhiasan, maupun lensa optik. Pemanfaatan gelombang ultrasonik yang dihasilkan dari alat ini, untuk ekstraksi bahan alam maupun sintesis senyawa organik belum banyak dipelajari. Proses ekstraksi dilakukan dengan menambahkan pelarut menggunakan perbandingan sampel:metanol 1:5 kemudian dimasukan ke dalam Ultrasonic 
Cleaner dan diekstrak selama 6 jam. Berlangsungnya proses ekstraksi ditandai dengan perubahan warna pelarut dari bening menjadi hijau. Mekanisme ekstraksi berbantuan ultrasonik dapat terjadi melalui fragmentasi, erosi, kapilariti, deteksturasi, dan sonoporasi (Chemat, dkk., 2017). Pada beberapa bahan alam, proses ekstraksi dapat terjdai melalui salah satu mekanisme atau gabungan dari beberapa mekanisme. Mekanisme ekstraksi yang terjadi pada ekstraksi daun pepaya dapat diketahui melalui studi lebih lanjut. Namun secara umum, ekstraksi disebabkan oleh gelombang kejut dari meletusnya kavitasi gelembung yang dihasilkan dari gelombang ultrasonik (Chemat, dkk., 2017). Hal ini yang menyebabkan reduksi ukuran partikel atau rusaknya permukaan molekul atau dinding sel dari sampel sehingga senyawa kimia yang terdapat di dalam bahan alam dapat tersekstrak. Proses ekstraksi lebih efektif karena membutuhkan waktu yang lebih singkat dan tidak memerlukan suhu tinggi (Wu, dkk., 2001; Chemat, dkk., 2017).

Hasil ekstrak metanol kemudian dievaporasi dan dilakukan skrining fitokimia untuk mengetahui metabolit sekunder yang dapat terekstrak dengan metode ini. Hasil skrining fitokimia pada Gambar 1 dan Tabel 1 menunjukkan hasil positif pada semua tes. Hal ini sejalan dengan penelitian sebelumnya bahwa ekstrak metanol mengandung saponin (Ayoola, dkk., 2008; Ayoola dan Adeyeye, 2010), flavonoid (Nugroho, dkk., 2017; Maisarah, dkk., 2013), terpenoid (Ayoola, dkk., 2008), alkaloid (Julianti, dkk., 2014), serta fenolik (Maisarah, dkk., 2013).

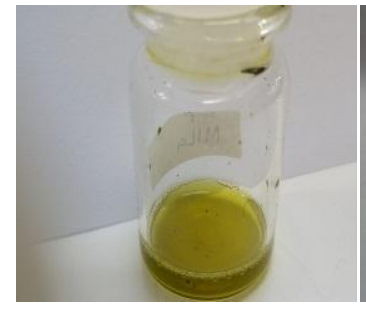

(a)

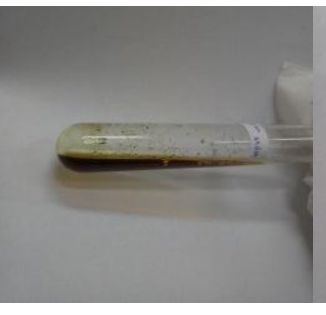

(b)

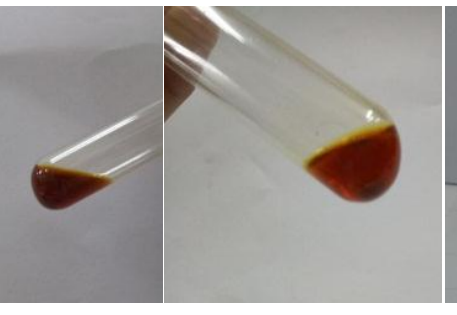

(c) (d)

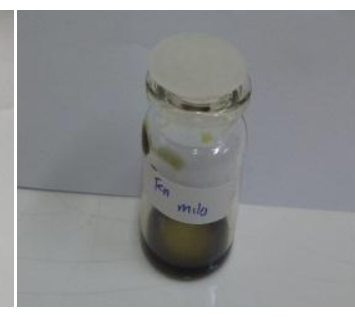

(e)

Gambar 1. Hasil uji skrining fitokimia ekstrak daun pepaya (a) saponin (b) flavonoid (c) terpenoid (d) alkaloid (e) fenolik 
Tabel 1. Hasil uji skrining fitokimia

\begin{tabular}{cccc}
\hline Uji & Sebelum uji & Setelah uji & Kesimpulan \\
\hline Saponin & Hijau bening & Hijau berbusa & + \\
Flavonoid & Hijau bening & Merah kecokelatan & + \\
Terpenoid & Hijau bening & Merah tua & + \\
Alkaloid & Hijau bening & Endapan merah tua & + \\
Fenolik & Hijau bening & Hijau kehitaman & + \\
\hline
\end{tabular}

Keterangan: (+): terdeteksi (-): tidak terdeteksi

Metanol merupakan pelarut universal yang dikenal dapat mengekstrak sebagian besar kandungan kimia dari bahan alam. Ekstrak metanol kemudian dipartisi cair-cair dengan pelarut n-heksana 1:1 menggunakan corong pisah untuk menghindari kemungkinan adanya molekul besar atau metabolit primer yang dapat mengganggu proses analisis yang terdapat di dalam ekstrak karena pada ekstrak tidak dilakukan pemurnian lebih lanjut sebelum dianalisis. Fasa nheksana hasil partisi kemudian dianalisis kuantitatif dengan KG-SM. Hasil kromatogram dan spektra massa hasil partisi cair-cair n-heksana pada Gambar 2, 3, 4 dan 5 serta Tabel 2 menunjukkan adanya tiga puncak yang diprediksikan merupakan neofitadiena, asam palmitat, serta metil linolenat.

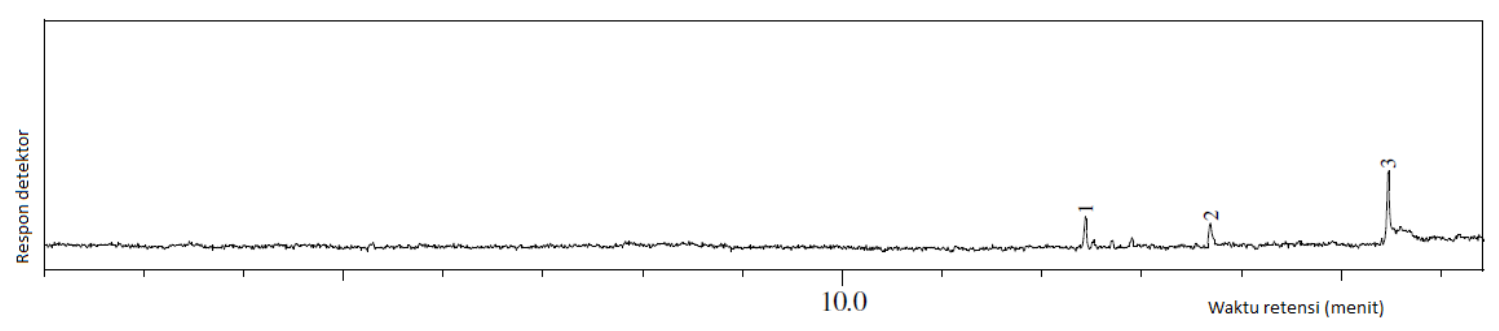

Gambar 2. Kromatogram ekstrak daun papaya 


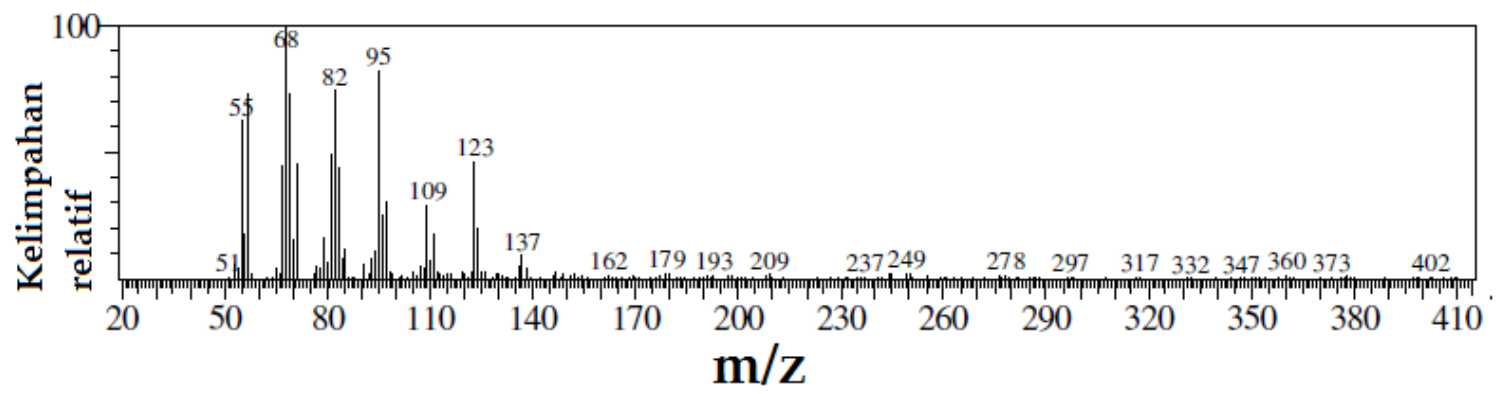

(a)

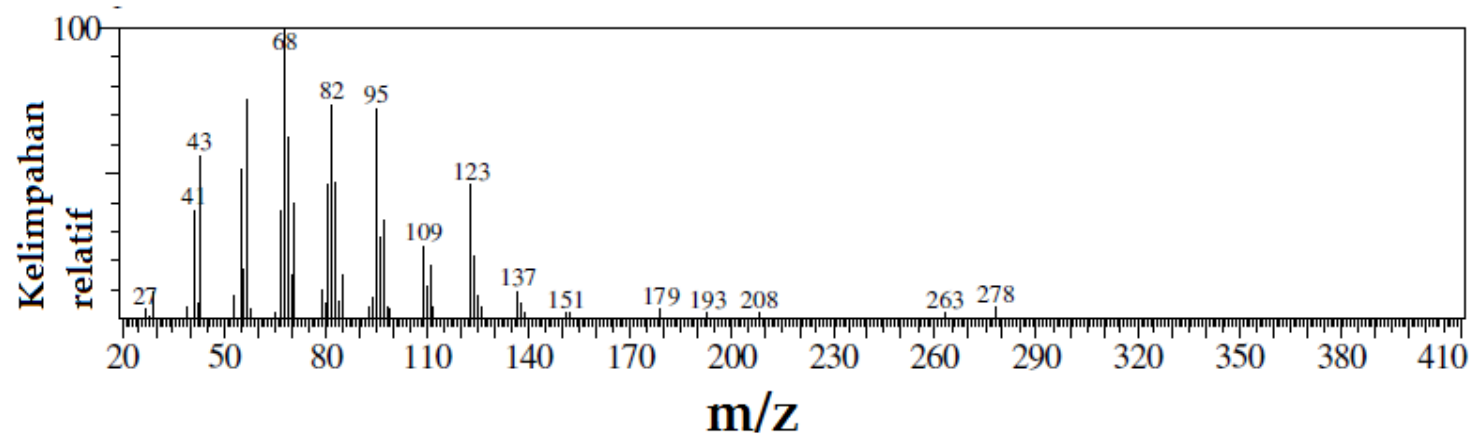

(b)

Gambar 3. Spektra massa (a) Puncak $1\left(t_{\mathrm{R}}: 12,433\right)$, puncak dasar: 68 (b) Library: Neofitadiena (2,6,10trimetil,14-etilen-14-pentadekena), SI: 93.

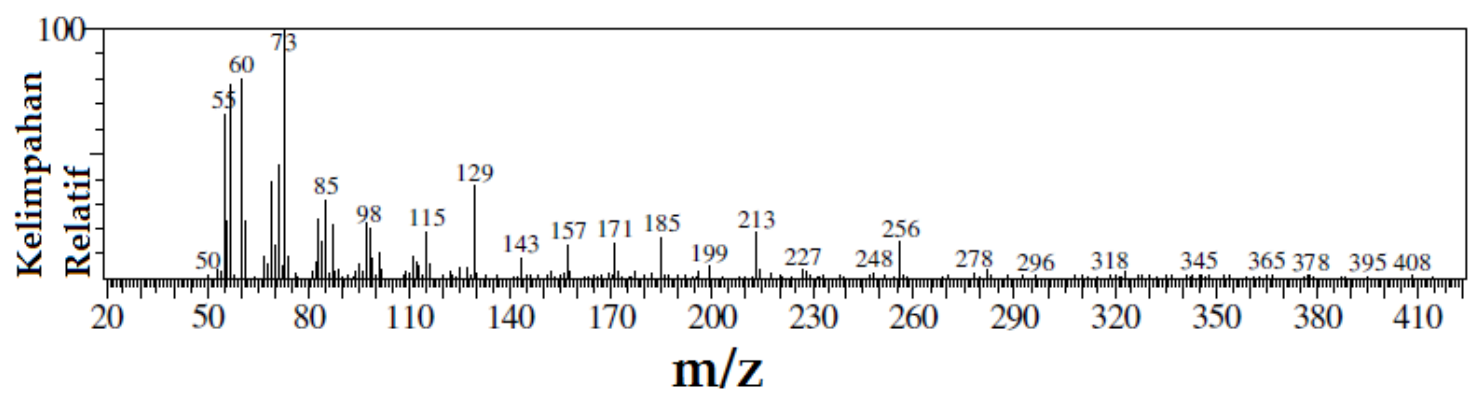

(a)

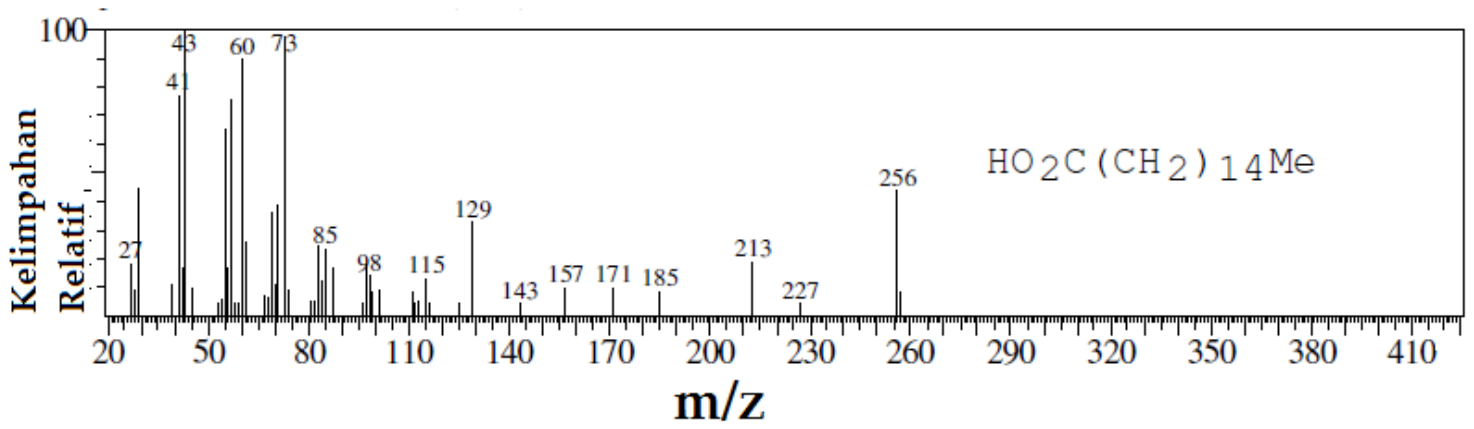

(b)

Gambar 4. Spektra massa (a) Puncak 2 ( $\mathrm{t}_{\mathrm{R}}:$ 13,692), puncak dasar: 73 (b) Library: Asam Palmitat (Asam Heksadekanoat), SI: 92. 


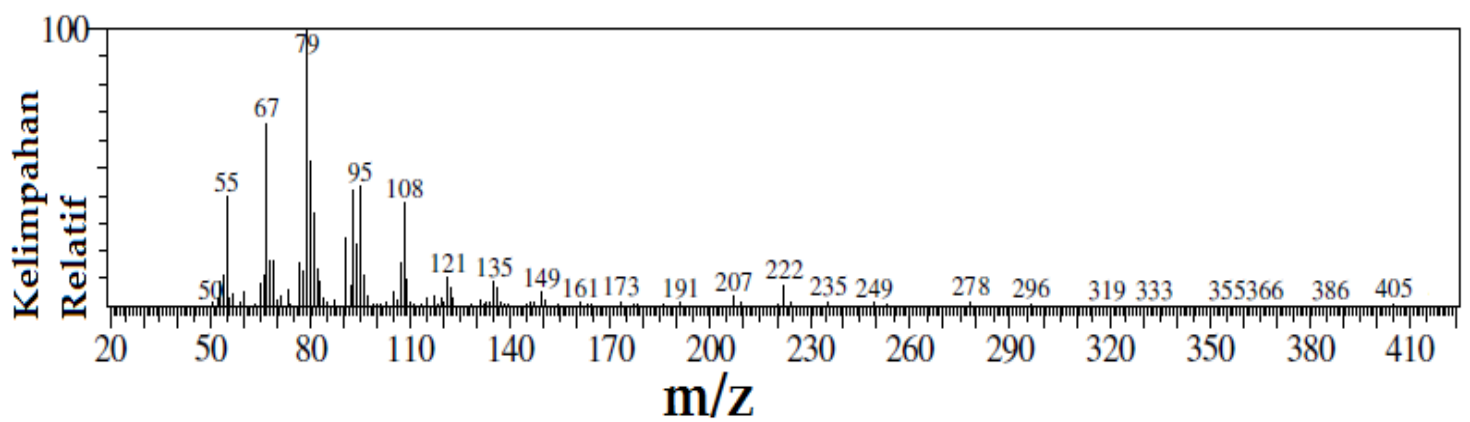

(a)

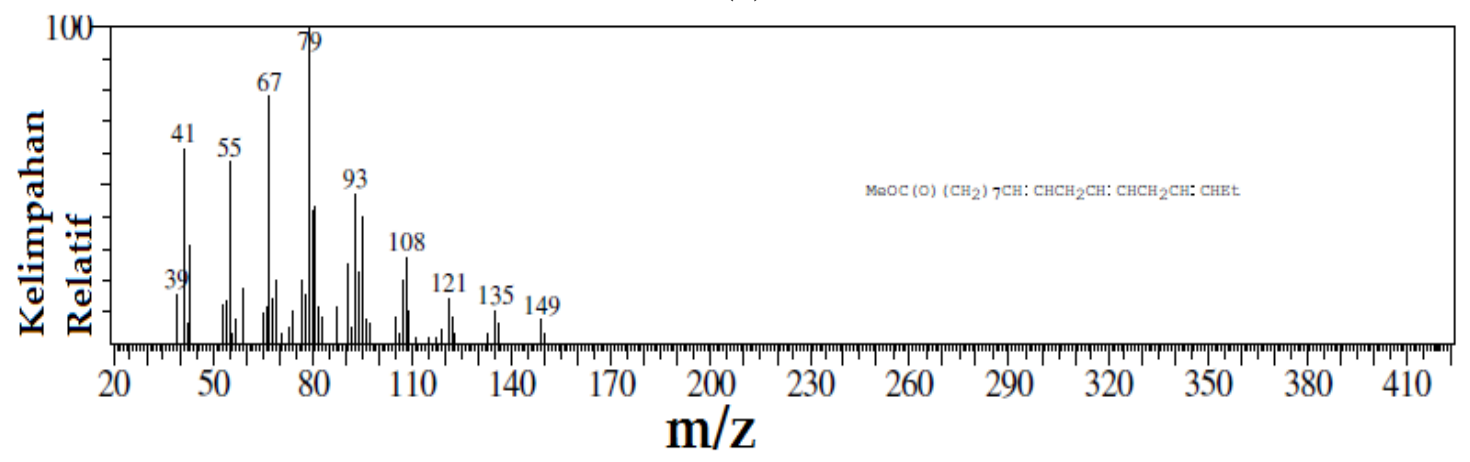

(b)

Gambar 5. Spektra massa (a) Puncak 3 ( $\left.t_{\mathrm{R}}: 15,475\right)$, puncak dasar: 79 (b) Library: Metil linolenat (asam 9,12,15-oktadekatrienoat), SI: 92.

Tabel 2. Prediksi senyawa ekstrak daun pepaya

\begin{tabular}{ccccccc}
\hline Puncak & $\begin{array}{c}\text { Waktu } \\
\text { Retensi } \\
\left(\mathrm{t}_{\mathrm{R}} / \text { menit }\right)\end{array}$ & $\begin{array}{c}\text { Prediksi } \\
\text { senyawa }\end{array}$ & $\begin{array}{c}\text { Rumus } \\
\text { senyawa }\end{array}$ & SI (\%) & $\begin{array}{c}\text { Kelimpahan } \\
\text { relatif (\%) }\end{array}$ & Rendemen \\
\hline 1 & 12,436 & Neofitadiena & $\mathrm{C}_{20} \mathrm{H}_{38}$ & 93 & 25,45 & $1,59 \%$ \\
2 & 13,689 & Asam Palmitat & $\mathrm{C}_{16} \mathrm{H}_{32} \mathrm{O}_{2}$ & 92 & 21,44 & $1,35 \%$ \\
3 & 15,472 & Metil Linolenat & $\mathrm{C}_{19 \mathrm{H}_{32} \mathrm{O}_{2}}$ & 92 & 53,11 & $3,33 \%$ \\
\hline
\end{tabular}

Neofitadiena merupakan metabolit sekunder kelas terpenoid (Ragasa, dkk., 2009), yang selain terdapat pada ekstrak daun pepaya juga terdapat pada minyak atsiri biji pepaya (Kuddus, dkk. 2016). Hasil analisis kuantitatif sejalan dengan skrining fitokimia yang menunjukkan bahwa ekstrak daun pepaya mengandung senyawa terpenoid. Metil linolenat merupakan metabolit pada tanaman yang memiliki peran sebagai penarik serangga (Ozawa, dkk., 2008), sedangkan asam palmitat merupakan asam lemak tak jenuh yang juga terkandung dalam biji pepaya (Marfo, dkk., 1986).

Prediksi senyawa yang telah teridentifikasi melalui KG-MS terdapat pada daun pepaya tersebut masih perlu 
dikaji ulang melalui studi lanjut. Perbedaan metode dan pelarut yang digunakan dapat mempengaruhi kandungan ekstrak yang didapatkan. Akhila dan Vijayalakshmi (2015) telah menganalisis kandungan ekstrak akuades daun pepaya muda. Beberapa kandungan senyawa diantaranya asam askorbat, carpaine, deoksikaempferol, kaempferol, deoksiquercetin, quercetin, dikumarol, asam kumaroilkuinat, kumarin, asam folat, sistin, homosistein, sistein sulfoksida, asam glutamat, asam p-kumaroil alkohol, dimetoksi fenol, umbelliferon, fenil alanin, kafeolil alkohol, metil nonil keton.

Dari hasil skrining fitokimia dan analisis dengan KG-SM, dapat dikatakan bahwa alat Ultrasonic Cleaner dapat digunakan untuk mengekstrak daun pepaya. Ekstraksi yang hanya dilakukan selama 6 jam dengan perbandingan pelarut 1:5, serta pada temperatur di bawah titik didih pelarut dengan bantuan gelombang ultrasonik dapat digunakan sebagai alterantif metode untuk mengekstrak bahan alam, terutama daun pepaya. Metode ini memiliki kelebihan dibandingkan dengan metode maserasi yang membutuhkan waktu yang lama serta banyak pelarut. Selain itu, metode ini dapat mereduksi kerusakan senyawa kimia yang tidak tahan oleh pemanasan serta mengurangi hilangnya senyawa volatil yang juga diakibatkan oleh pemanasan seperti pada metode ekstraksi dengan destilasi maupun sokhletasi. Hasil analisis KG-SM yang hanya dapat mendeteksi 3 puncak senyawa merupakan bahan kajian untuk penelitian yang akan datang.

\section{Kesimpulan}

Hasil skrining fitokimia menunjukkan ekstrak daun pepaya mengandung metabolit sekunder kelas saponin, alkaloid, terpenoid, flavonoid, serta fenolik. Hasil analisis dengan KGSM menunjukkan ekstrak metanol yang telah dipartisi dengan n-heksana mengadung senyawa neofitadiena, asam palmitat, serta metil linolenat. Alat Ultrasonic Cleaner yang dapat menimbulkan irradiasi gelombang ultrasonik yang dapat digunakan sebagai alternatif untuk mengekstrak daun pepaya pada suhu rendah, pelarut yang relatif lebih sedikit, serta waktu yang relatif lebih singkat.

\section{Referensi}

Ahmad, N., Fazal, H., Ayaz, M. Abbasi, B.H., Mohammad, I., dan Fazal, L., 2011, Dengue Fever Treatment with Carica papaya Leaves Extracts, Asian Pac J Trop Biomed. 1(4): 330-333. 
Akhila, S.dan Vijayalakshmi, N.G., 2015, Phytochemical Studies on Carica papaya Leaf Juice, Int $J$ Pharm Sci Res. 6(2): 880-883.

Atun, S., 2014, Metode Isolasi dan Identifikasi Struktur Senyawa Organik Bahan Alam, Jurnal Konservasi Cagar Budaya Borobudur 8(2): 53-61.

Ayoola, G.A., Coker, H.A.B., Adesegun, S.A., Adepoju-Bello, A.A., Obaweya, K., Ezennia, E.C., Atangbayila, T.O., 2008, Phytochemical Screening and Antioxidant Activities of Some Selected Medicinal Plants Used for Malaria Therapy in Southwestern Nigeria, Trop. J. Pharm. Res. 7 (3): 1019-1024.

Ayoola, P.B. dan Adeyeye, A, 2010, Phytochemical and Nutrient Evaluation of Carica papaya (Pawpaw) Leaves, IJRRAS 5 (3): 325:28.

Chemat, F., Fabiano-Tixier, A.S., Vian. M.A., dan Allaf, T., 2015, Solvent-free Extraction of Food and Natural Products, Trends Analyt. Chem. 71: 157-168.

Chemat, F., Rombaut, N., Sicaire, A-G., Meullemiestre, A., Fabiano-Tixer, A.S., Albert-Vian, M., Pal, M. and Chandrashekar, K., 2017, Ultrasound Assisted Extraction of Food and Natural Products Mechanisms, Techniques, Combinations, Protocols and Applications: A Review, Ultrason. Sonochem. 3: 540-560.

Cragg., G.M. dan Newman, D.J., 2013, Natural Products: A Continuing Source of Novel Drug Leads, Biochim. Biophys. Acta 1830: 3670-3695.
Jiménez, V.M., Mora-Newcomer, E., dan Gutiérrez-Soto, M.V., 2013, Plant Genetics and Genomics: Crops and Models, Chapter 2: Biology of the Papaya Plant, Volume 10, Berlin: Springer.

Julianti, T., Oufir, M., dan Hamburger, M., 2014, Quantification of the Antiplasmodial Alkaloid Carpaine in Papaya (Carica papaya) Leaves, Planta Med. 80: 1138-1142.

Kuddus, M., Arif, J.M., Ali, A., Kausar, M.A., Shahid, SMA, Parveen, K, dan Siddiqui, W.A., 2016, Chemical Fingerprinting of Bioactive Compounds of Carica papaya Linn (Indian Variety) Seed Oil, Biochem. Cell. Arch. 16(1): 9-20.

Luo, Y, Cobb, R.E., dan Zhao, H., 2014, Recent Advances in Natural Product Discovery, Current Opinion in Biotechnology 30: 230-237.

Maisarah, A.M., Amira, N.B., Asmah, R., dan Fauziah, O., 2013, Antioxidant Analysis of Different Parts of Carica papaya, International Food Research Journal 20(3): 1043-1048.

Marfo, E.K., Oke, O.L., dan Afolabi, O.A., 1986, Chemical Composition of Papaya (Carica papaya) Seeds, Food Chemistry 22: 259-266.

Nugroho, A., Heryani, H., Choi, J.S., dan Park, H.J., 2017, Identification and Quantification of Flavonoids in Carica papaya Leaf and Peroxynitritescavenging Activity, Asian Pac. J. Trop. Biomed. 7(3): 208-213. 
Otsuki, N., Dang, N.H., Kumagai, E., Kondoc, A., Iwataa, S., dan Morimotoa, C., 2010, Aqueous Extract of Carica papaya Leaves Exhibits Anti-Tumor Activity and Immunomodulatory Effects, $J$. Ethnopharmacol.127: 760-767.

Ozawwa, R., Shiojiri, K, Sabelis, M.W., dan Takabayashi, J., 2008, Maize Plants Sprayed with Either Jasmonic Acid or Its Precursor, Methyl Linolenate, Attract Armyworm Parasitoids, But the Composition of Attractants Differs, Entomol Exp Appl. 129: 189-199.

Ragasa, C.Y., Tsai, P.W., dan Shen, C.C., 2009, Antimicrobial Terpenoids from Erigenon sumatrensis, NRCP Research Journal 10(1): 27-32.
Sari, D.K., Wardhani, D.H., Prasetyaningrum, A., 2013, Kajian Isolasi Senyawa Fenolik Rumput Laut Eucema Cottonii Berbantu Gelombang Micro dengan Variasi Suhu dan Waktu, Jurnal Teknik Kimia 19(3): 38-43.

Vuong, Q.V., Hiruna, S., Roacha, P.D., Bowyer , M.C., Phillips, P.A., Scarlett, C.J., 2013, Effect of Extraction Conditions on Total Phenolic Compounds and Antioxidant Activities of Carica papaya Leaf Aqueous Extracts, $J$ Herb Med. 3: 104-111.

Wu., J., Lin, L., dan Chau, F., 2001, Ultrasound-assisted extraction of Ginseng Saponins from Ginseng Roots and Cultured Ginseng Cells, Ultrason. Sonochem. 8: 347-352. 